\title{
PREDICTION OF AIR PERMEABILITY OF KNITTED FABRIC BY USING COMPUTATIONAL METHOD
}

\author{
Muhammad Owais Raza SIDDIQUI ${ }^{1,2, *}$, Muhammad ALI ${ }^{1}$, Muhammad ZUBAIR ${ }^{1}$ and Danmei SUN ${ }^{2}$ \\ ${ }^{I}$ Department of Textile Engineering, NED University of Engineering and Technology, Karachi, 75270, Pakistan \\ ${ }^{2}$ School of Textiles and Design, Heriot Watt University, TD1 3HF, UK
}

Received: 05.04.2018

Accepted: 19.09 .2018

\begin{abstract}
Air permeability is one of the very important factors which need to be considered at the development stage of textile fabrics because it affects the comfort of the clothing. During normal and extreme environmental conditions human body releases heat and the heat can be controlled by the air exchange between the body and clothing microclimate and the external environment; the exchange phenomena depends on the air permeability of the fabric. The air permeability of fabric can be evaluated by both the experimental and computational methods. In this work, a computational method is used for the prediction of air permeability of fabrics. The geometrical model of weft knitted structures was generated by using the actual dimensional parameters of the fabric and was further analysed by applying appropriate boundary conditions. The simulated results obtained from computational analysis were compared to the experimental results. Furthermore, the validated models were further used to predict and analyse the effect of stitch length, stitch density and fibre volume fraction on the air permeability of the fabric.
\end{abstract}

Keywords: Air Permeability, Computational Fluid Dynamics, Computational Methods

Corresponding Author: Muhammad Owais Raza Siddiqui E-mail: orazas@neduet.edu.pk / DOI: 10.32710/tekstilvekonfeksiyon.482877

\section{INTRODUCTION}

Air permeability plays an important role in the performance of textile materials and it depends on the construction of the fabrics. It can be varied with different fabric parameters such as level of yarn twist, yarn count and fabric construction. It is difficult to establish the relation of air permeability with all fabric construction parameters. However, two different methods have been used in the evaluation of the air permeability of a fabric: one is by the number of pores per unit area of a fabric. The air permeability of fabric directly depends on the porosity of the fabric which is depended on three factors: area of the pore, depth of pore and the number of pores in a fabric (1). The second method is to measure the amount of fluid that can passes through a fabric under different pressures (2). The first primary investigation of air permeability for fabrics conducted by Rubber (3) had been mainly based on Darcy's law:

$Q=\frac{K A \Delta P}{\mu L}$

where $Q$ the total volumetric discharge in unit time $\left(\mathrm{m}^{3} / \mathrm{sec}\right), A$ is the cross sectional area of the porous medium $\left(\mathrm{m}^{2}\right), \Delta P / L$ is the pressure gradient (pa/m), $\mu$ is the fluid viscosity (Pa.sec) and $K$ is the permeability $\left(\mathrm{m}^{2}\right)$.

The relationship between air permeability and structural properties of knitted fabrics was analysed by Mavruz et al. (4) using a combed ring spun yarn and a compact yarn. They concluded: (i) the air permeability increases for fabrics with lower courses and yarn count. Therefore, loose surface of the fabric has increased air permeability, (ii) knitted fabrics become tighter after washing relaxation, but air permeability decreases with the increase of the weight and thickness, (iii) air permeability of fabrics knitted with ring yarns is slightly lower than that of compact yarns, and (iv) air permeability increases with the increased loop length and decreased tightness of knitted fabrics.

Kumar et al. (5) studied the air permeability of knitted fabrics produced by a different spinning system which subjected to full relaxed, wet and dry states respectively. The results revealed that the stretched and un-stretched state of the fabric has a high impact on the air permeability of the fabric. The air permeability of textile structures can also be 
evaluated by the computational method by applying boundary conditions.

Rief et al. (6) developed a 3D model of woven fabric by virtual and 3D reconstruction method in order to evaluate the air permeability by Computational Fluid Dynamics (CFD) simulation. Kyosov et al. (7) investigated the air permeability through the thickness of the layered woven fabric by means of CFD, using the theory of jet systems. They also analysed the effect of distance between the layers on air flow velocity.

Mezarciöz et al. (8) predicted the air permeability of a plain knitted fabric through thickness by using the CFD as a numerical tool based on the theoretical model developed by Ogulata and Mavruz (2). They developed 3D model of knitted fabric where the loops were assumed to be composed of ideal yarns having a constant diameter and circular cross-section throughout the entire length, neglecting the yarn deformation at the crossover points. However, they claimed that their predicted results were very close to experimental results with the consideration of the above assumptions.

Dabiryan et al. (9) analysed the air permeability of nonwoven fabric by using a 3D model which generated by assembling simulated webs based on Poisson's random number process. They compared the results of air permeability obtained from the experimental method with the computational method in the form of outlet pressure which shows good agreement. Dehkordi et al. (10) investigated the effect of loop length on air permeability of rib and interlock structures by CFD. The research revealed that the air permeability of the knitted fabric reduced with the increase of loop density.

The overall aim of this research was to develop computational models with the actual construction parameters of a knitted fabric to simulate and predict its air permeability. Furthermore, the effect of structural parameters of plain weft knitted fabric on air permeability will be analysed. In this work the 3D model of the knitted fabric created by the parametric method in which the geometric model of knitted fabric is generated by the actual dimension of the fabric (11-13). In comparison to generic geometric modeling approach (14-20) the parametric method is able to predict the porosity of the fabric more accurately (11).

\section{MATERIAL AND METHOD}

\section{Material}

A polyester plain weft knitted fabric was used to numerically study the air permeability of the fabric. The predicted results from CFD simulation were compared to the results from experiment. Table 1 shows the experimental results of their air permeability tested by SDL Atlas air permeability tester M021S according to the method specified by ASTM D73796 under a constant pressure difference of 100 pa (21), the value of permeability (in $\mathrm{mm} / \mathrm{sec}$ ) is calculated by Darcy's law Equation (2).

Furthermore, the areal density of the fabric (GSM), yarn count, number of courses and wales per $\mathrm{cm}$, length of the loop, and the thickness of the fabric were measured according to BS 12127:1998, BS 2865:1984, BS 14971:2006, BS 14970:2006 , and FAST-1 compression meter (under $2 \mathrm{gf} / \mathrm{cm}^{2}$ ) respectively. Before testing, the samples were conditioned for 48 hours in standard conditions of $20 \pm 2{ }^{\circ} \mathrm{C}$ temperature and $65 \pm 2 \%$ relative humidity. Five measurements were performed for each sample and all knitted fabrics were produced on 10 and 20 gauge, 4 inches diameter circular knitting machines.

\section{Computational Analysis}

The following methods were adapted to calculate the air permeability of the plain weft knitted fabric: (i) to develop three dimensional model of plain weft knitted structure by using unit cell approach; (ii) to examine the air permeability of the plain weft knitted fabric by applying computational fluid dynamics with specific boundary conditions; and (iii) to compare the air permeability results between computational and experimental for model validation (shown in Figure 1).

\section{D geometrical modelling}

Many researchers such as Pierce (14), Doyle (15), Shinn (16), Leaf and Glaskin (17), Leaf (18), Munden (19), Postle (20), Kurbak (22), and Demiroz and Dias (23) have proposed geometrical models of knitted fabrics. In this work, the 3D model of the plain weft knitted fabric was created by sweeping circular cross-section of yarn along the yarn path as a one-dimensional line that shows the three-dimensional space of the centerline of the yarn as shown in Figure 2 (a) (c). The yarn path can be described as the distance across the yarn which is the function of position in the $3 D$ space. The most versatile and collective way to define the yarn path is divided into the discrete position with particularize number across the length of the yarn studied and master node and interpolate between the points. The interpolation function should have minimum space between the path of the yarn and the general answer to this complication is the use of splines.

Table 1. Specifications of plain weft knitted fabrics

\begin{tabular}{|c|c|c|c|c|c|c|c|c|}
\hline $\begin{array}{c}\text { Fabric } \\
\text { Code }\end{array}$ & $\begin{array}{c}\text { Yarn } \\
\text { count } \\
(\text { Tex })\end{array}$ & $\begin{array}{c}\text { Yarn } \\
\text { diameter } \\
(\mathbf{m m})\end{array}$ & $\begin{array}{c}\text { Wales } \\
\text { per } \mathbf{~ c m}\end{array}$ & $\begin{array}{c}\text { Courses } \\
\text { per } \mathbf{~ c m}\end{array}$ & $\begin{array}{c}\text { Stitch } \\
\text { length } \\
(\mathbf{m m})\end{array}$ & $\begin{array}{c}\text { Fabric } \\
\text { thickness } \\
(\mathbf{m m})\end{array}$ & $\begin{array}{c}\text { Areal } \\
\text { density } \\
\left(\mathbf{g} / \mathbf{m}^{2}\right)\end{array}$ & $\begin{array}{c}\text { Air permeability } \\
(\mathbf{m m} / \mathbf{s e c})\end{array}$ \\
\hline F1 & 20 & 0.156 & 6 & 11.22 & 4.49 & 0.39 & 60.4 & 10546.6 \\
\hline F2 & 20 & 0.156 & 7.2 & 10.96 & 4.32 & 0.41 & 68.1 & 9313.2 \\
\hline F3 & 20 & 0.156 & 9.5 & 11.4 & 3.94 & 0.43 & 85.3 & 7605.6 \\
\hline F4 & 20 & 0.156 & 11.5 & 12.7 & 3.55 & 0.46 & 103.6 & 6016.2 \\
\hline F5 & 20 & 0.156 & 12 & 13.71 & 3.45 & 0.473 & 113.5 & 5066.4 \\
\hline
\end{tabular}




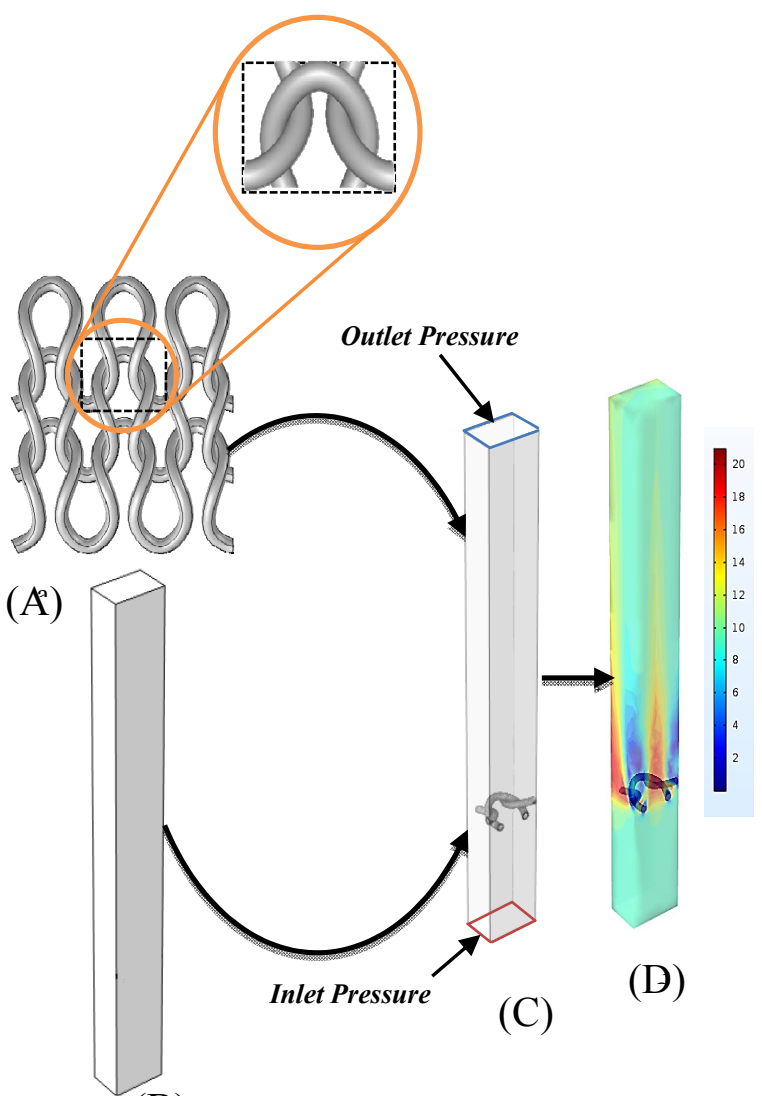

(B)
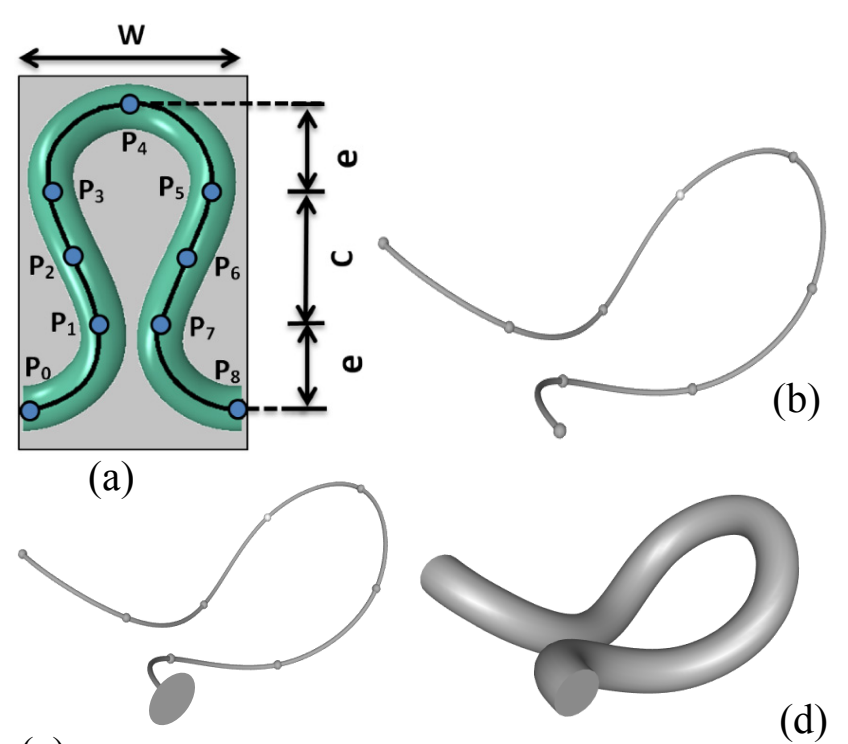

(c)

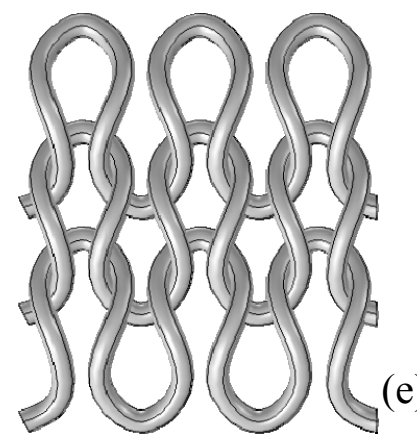

(e)

Figure 1. Methodology to evaluate air Permeability: (a) 3D model of plain weft knitted fabric, (b) air domain, (c) air domain with unit cell model, (d) simulated velocity profile

A yarn path or central axis was constructed by connecting nine points which are defined as a function of course (C), wales (W) spacing and a parametric value "e" as shown in Figure 2 (a). The course and wales spacing can be calculated by using the number of wales and courses per unit length, the parametric value "e" which makes the geometric model different from generic approach (11-17). The parametric value "e" mainly depends upon the average loop height $(\mathrm{H})$ of the knitted fabric as shown in Equation (2); it can be calculated through image analysis. The loop length of the plain weft knitted fabric is mainly affected by the parametric value "e" which is retrieved from the actual image of the fabric in case of generic geometric modeling approach, where the stitch length of knitted fabric calculated by using circular arc and straight line.

$$
H=C+2 e
$$

The detailed information about the geometrical modelling can be found in published work by the authors (20-22). Figure 2 (b) shows the geometrical model developed in COMSOL Multiphysics ${ }^{\circledR}$ by using the above described parametric method as shown in Figure 2 (a).

\section{Analysis}

The unit cell method is used to analyse the air permeability of the plain weft knitted fabric by using the free and porous media flow interface as shown in (Figure 3).

The model couples the free fluid and porous media flow through the yarn in porous media interface. The stationary Navier-Stokes Equations describe the fluid flow in the freeflow regions, in free volume the momentum and continuity Equations (3) and (4) are used as:

$$
\begin{aligned}
& \rho(u . \nabla) u=\nabla \cdot\left[-\rho I+\mu\left(\nabla u+(\nabla u)^{\tau}\right]+F\right. \\
& \rho \nabla . u=0
\end{aligned}
$$

where $\rho, u, \mu$ and $F$ is the density, velocity, dynamic viscosity and volume force of air. 


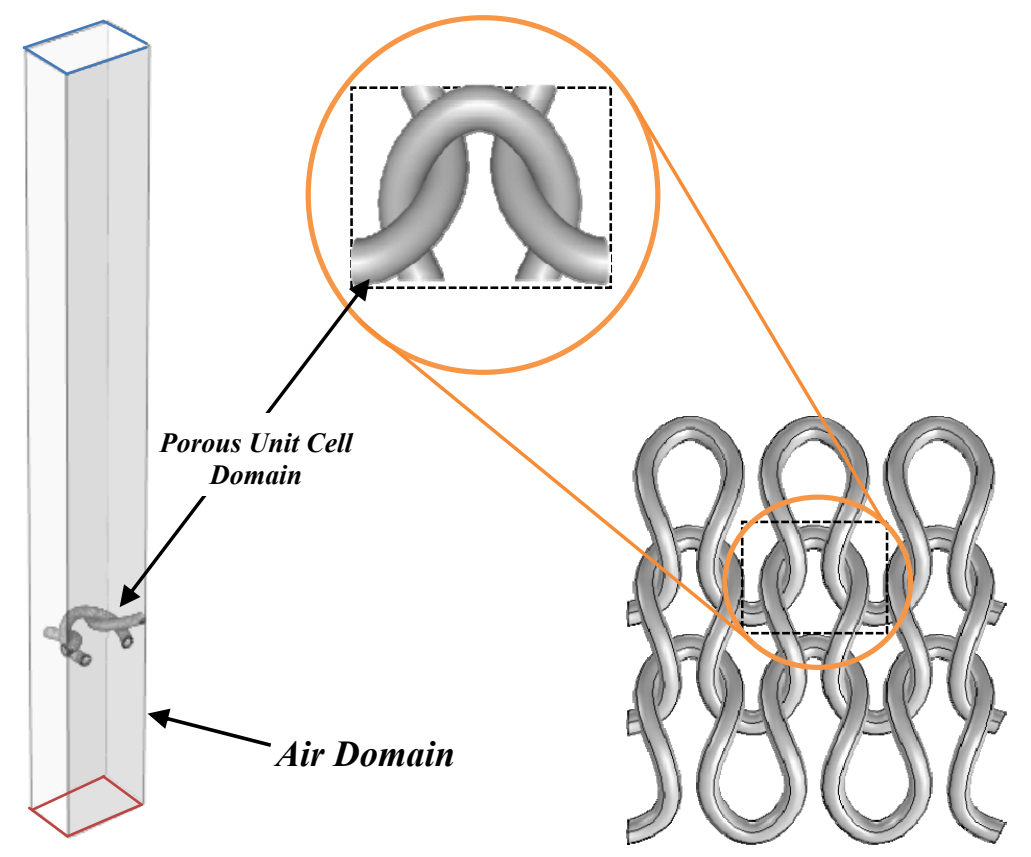

Figure 3. Simulation setup for air permeability of plain weft knitted fabric

In the porous yarn, the Brinkman Equations for porous media apply. The momentum and continuity Equations (5) and (6) are used as:

$$
\frac{\rho}{\epsilon_{p}}\left((u . \nabla) \frac{u}{\in p}\right)=\nabla .\left[-\rho I+\frac{\mu}{\epsilon_{p}}\left(\nabla u+(\nabla u)^{\tau}\right)-\frac{2 \mu}{3 \in p}(\nabla . u) I\right]-\left(u K^{-1}+\beta_{F}|u|+\frac{Q_{b r}}{\epsilon_{p}}\right) u+F
$$

$$
\rho \nabla u=Q_{b r}
$$

where $\in p$ and $K$ are the porosity and air permeability tensor of yarn.

Yarn porosity $(\in p)$ of knitted fabrics can be calculated by Equation (7) and (8) which is 0.248 .

$$
\in p=1-V_{f}
$$

where $V_{f}$ is the fibre volume fraction of yarn which can be calculated by Equation (7).

$$
V_{f}=\frac{4 \times T_{y}}{d^{2} \times 10^{3} \rho_{f}}
$$

where $\mathrm{T}_{y}$ is the yarn count (Tex) and $\rho_{f}$ is the density of fibre $\left(\mathrm{g} / \mathrm{cm}^{3}\right)$.

The air permeability of yarn $(K)$ along the transverse direction can be calculated by Equation (9) by using Gebart model (24) which is $2.38 \mathrm{e}-{ }^{14} \mathrm{~m}^{2}$.

$$
k=\frac{16 R_{f}^{2}}{9 \pi \sqrt{6}}\left(\sqrt{\frac{V_{\max }}{V_{f}}}-1\right)^{\frac{5}{2}}
$$

where $V_{\max }$ is the maximum fibre volume fraction which is $\pi / 2 \sqrt{3}$ of hexagonal fibre array and $R_{f}$ is the radius of fibre which is $5.58 \mu \mathrm{m}$.

A unit cell model of plain weft knitted fabric placed inside the pipe like domain in which the inlet domain length of $3 \mathrm{~mm}$ and outlet domain length of $9 \mathrm{~mm}$ to ensure that the flow is fully developed. The difference of pressure is maintained on the two faces of the fabric, for that purpose, a constant pressure of $100 \mathrm{~Pa}$ is applied at inlet corresponding to the experiment and $0 \mathrm{~Pa}$ is applied at the outlet. No slip condition is applied on the surface of the yarn; this means that there is no flow velocity at the surface of the yarn. Symmetry boundary condition is applied at the side of the wall because the unit cell is the part of the infinite plain weft knitted fabric. The geometrical model was meshed by a tetrahedral element with the optimum element size and further refinement will not affect the results.

\section{RESULTS AND DISCUSSION}

In steady state flow scheme when convergence is achieved with low error. Their air permeabilities of the plain weft knitted fabrics evaluated in the post-processing are shown in Table 2 and Figure 4 (a). The low mean absolute error $(5.192 \%)$ and high $R^{2}(0.9681)$ shows the strong correlation between the results from CFD and the experiment. 
Furthermore, Figure 4 (b) shows the statistical analysis (ANOVA) of regression model computed using JMP (Version 11.0.0). A probability value of less than $5 \%$ evidenced that the CFD method described above can be used to predict the air permeability of knitted structures. Figure 5 shows the velocity magnitude. The flow is almost homogeneous in the free domain. The flow of air is concentrated across the fabrics, showing pressure drops; it means that the air flow velocity is increased across the porous structure of the knitted fabric.
Table 2. Air permeability obtained from CFD and experiment

\begin{tabular}{|c|c|c|c|}
\hline \multirow{2}{*}{$\begin{array}{c}\text { Fabric } \\
\text { Code }\end{array}$} & \multicolumn{2}{|c|}{$\begin{array}{c}\text { Air permeability } \\
\text { (mm/sec) }\end{array}$} & \multirow{2}{*}{$\begin{array}{c}\text { Absolute } \\
\text { Error \% }\end{array}$} \\
\cline { 2 - 3 } & $\begin{array}{c}\text { CFD } \\
\text { Results }\end{array}$ & $\begin{array}{c}\text { Experimental } \\
\text { Results }\end{array}$ & \\
\hline F1 & 10095.1 & 10546.6 & 4.28 \\
\hline F2 & 9880.8 & 9313.2 & 6.09 \\
\hline F3 & 7438.5 & 7605.6 & 2.19 \\
\hline F4 & 6418.6 & 6016.2 & 6.69 \\
\hline F5 & 5406.1 & 5066.4 & 6.71 \\
\hline \multicolumn{3}{|c|}{ Mean Absolute error \% } & 5.192 \\
\hline
\end{tabular}
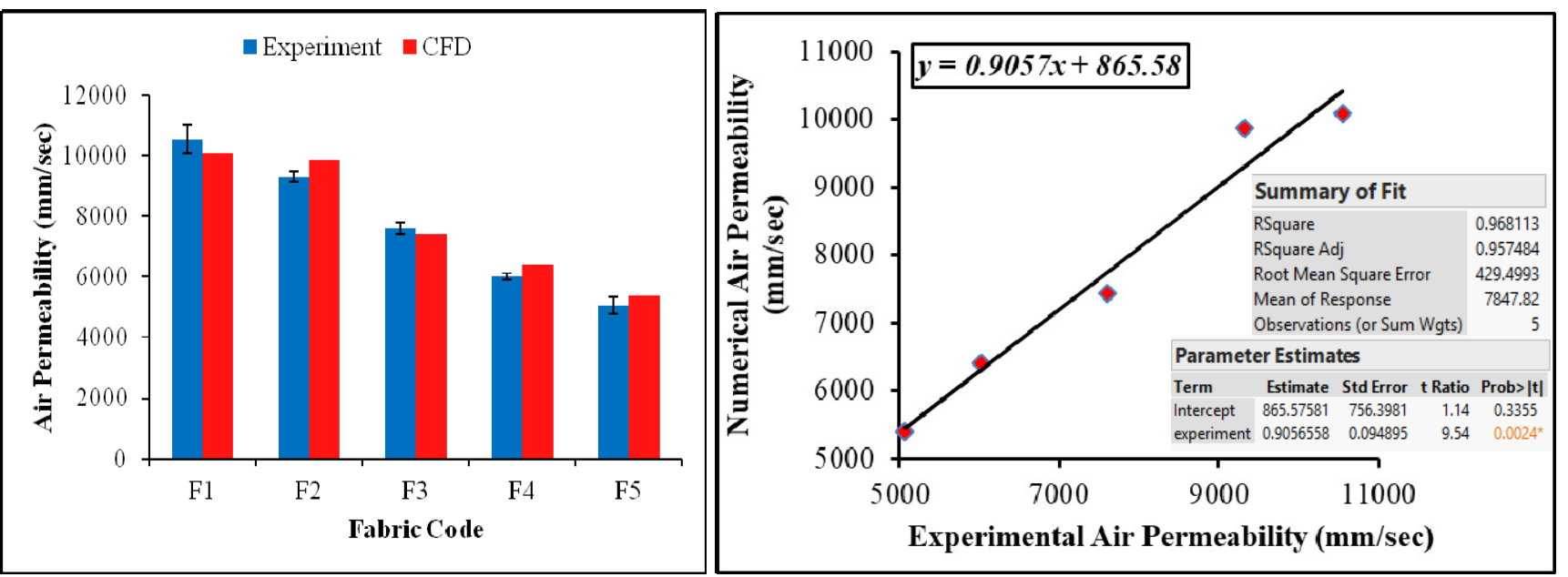

Figure 4. Comparison of air permeability between CFD and experiment
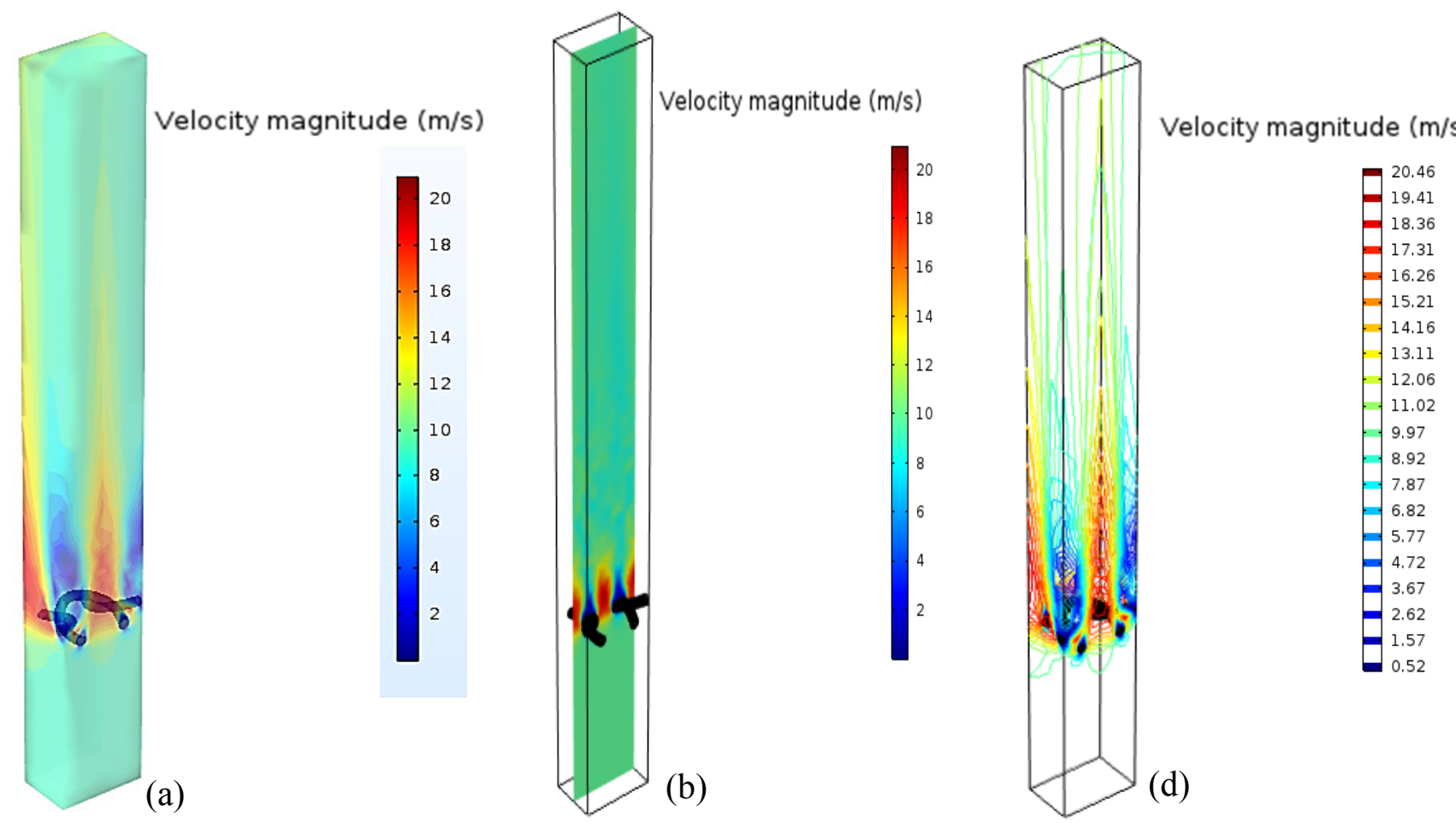

Figure 5. Simulated results of plain weft knitted fabric F2: (a) Magnitude of the velocity field in the free and porous plain weft knitted domains, (b) Slice view of velocity magnitude and (c) Contour of velocity magnitude 
Figure 6 (a) gives a direct view of relationships between air permeability and various fabric parameters: (i) by increasing the stitch density, the air permeability of the knitted fabric decreases caused by the reduced pores size between the courses and wales within the fabric. (ii) Increasing the stitch density by keeping the yarn count constant the fabric areal density (GSM) of the fabric increases; GSM of the fabric is directly related to the fibre volume fraction in the fabric.

The higher the fibre volume fraction the lower the porosity of the fabric, and (iii) air permeability has a direct relation with the porosity of the fabric because it provides more open area to air flow as shown in Figure 6 (b), the higher the loop length, the lower the stitch density which increases the porosity of the fabric. The loop length has a positive effect on the air permeability as shown in Figure 6 (c). (iv) As shown in Figure $6(\mathrm{~d})$, the air permeability in the transverse direction of the fabric decreases with the increase of thickness because the air has to travel through the longer pores in case of a thicker fabric.

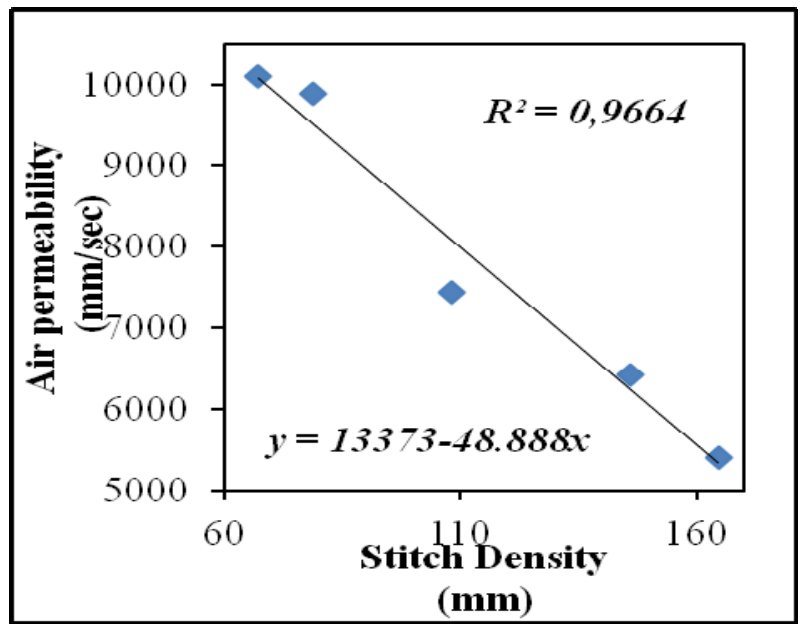

(a)

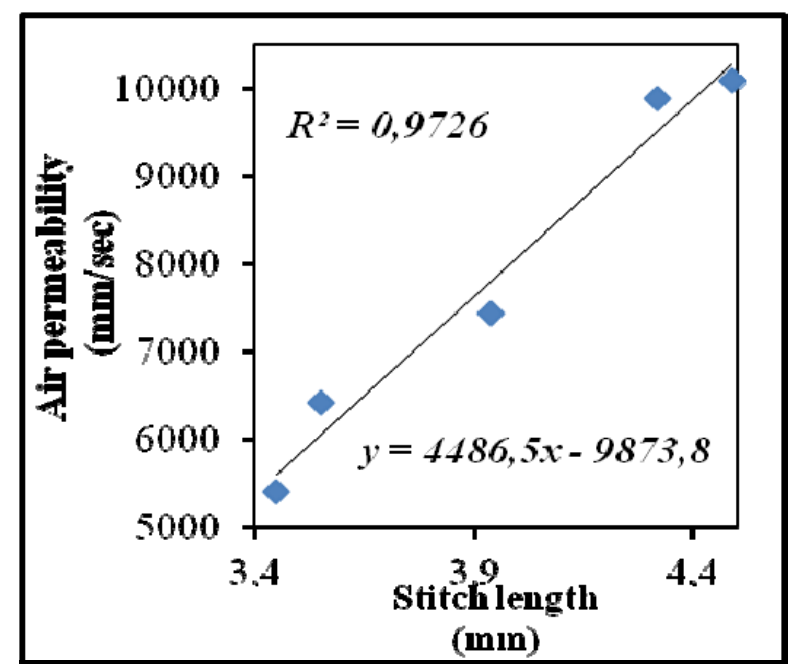

(c)

\section{CONCLUSIONS}

In this work, a 3D unit cell model of plain weft knitted fabric is used to simulate the air permeability by CFD. Air permeability is an important property of textile fabric which has a significant impact on the comfort of the wearer and closely related to the structure of the fabric. The research revealed that the air permeability decreases with the increase of the stitch density. Higher stitch density means more compact structure and the stitch length also reduces which restricts the flow of air.

The high coefficient of determinations show the actual and predicted air permeability values agreed well with each other. Furthermore, the statistical analysis revealed that the regression model between experimental and predicted air permeabilities have a strong linear relationship. The low mean absolute error value shows good predictability of the developed method for the prediction of the air permeability of different fabric structures. Further research can be carried out on knitted fabrics with different structures and diversified materials using the same technique to analyse the effect of air permeability by using different statistical analysis tools.

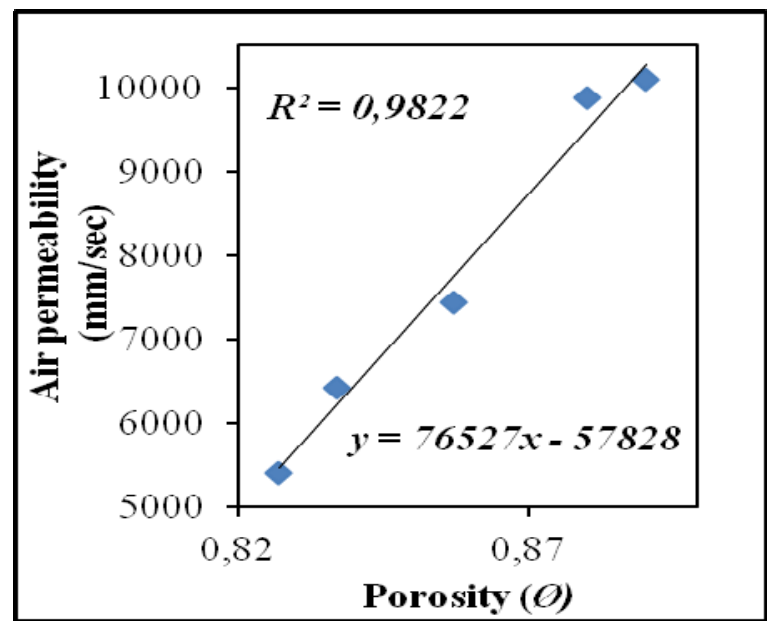

(b)

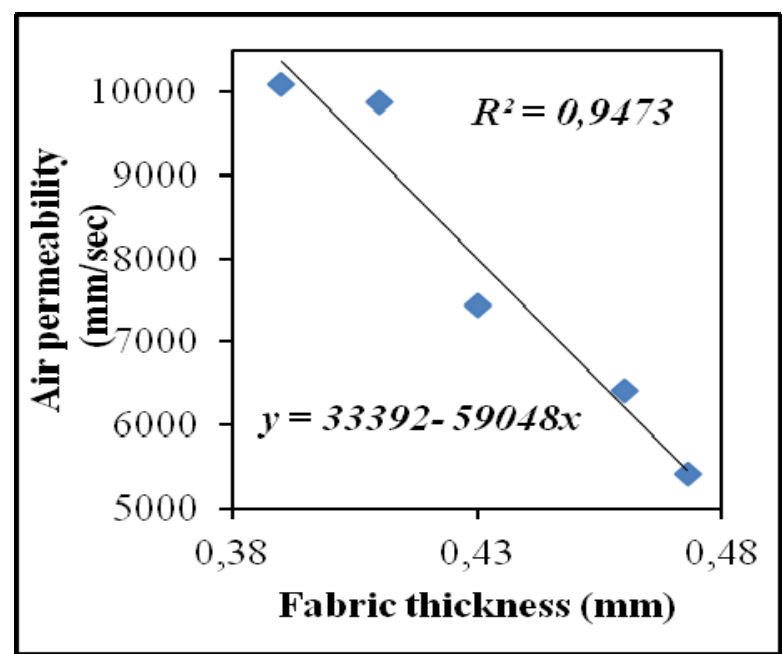

(d)

Figure 6. Relationship between predicted air permeability and (a) stitch density, (b) porosity, (c) stitch length, and (d) fabric thickness 


\section{REFERENCES}

1. Ogulata, R.T., 2006, “Air permeability of woven fabrics”, Journal of Textile and Apparel, Technology and Management, Vol: 5(2): pp: 1-10.

2. Ogulata, R.T. and Mavruz, S., 2010, "Investigation of porosity and air permeability values of plain knitted fabrics", Fibres \& Textiles in Eastern Europe, Vol: 18(5): pp: 71-75.

3. Senoguz, M., et al., 2001, "Simulations and experiments on low-pressure permeation of fabrics: Part II-The variable gap model and prediction of permeability" Journal of composite materials, Vol:35(14), pp: 1285-1322.

4. Mavruz, S. and Ogulata, R.T., 2011, "Investigation of air permeability of single jersey fabrics with different relaxation states", The Journal of The Textile Institute, Vol:102(1), pp: 57-64.

5. Kumar, V., Sampath, V.R. and Prakash, C., 2016, "Investigation of stretch on air permeability of knitted fabrics part II: effect of fabric structure", The Journal of The Textile Institute, Vol: 107(10), pp: 1213-1222.

6. Rief, S., et al., 2011, "Modeling and CFD-simulation of woven textiles to determine permeability and retention properties", AUTEX Research Journal, Vol: 11(3), pp: 78-83.

7. Kyosov, M., Angelova, R.A. and Stankov, P., 2016, "Numerical modeling of the air permeability of two-layer woven structure ensembles", Textile Research Journal, Vol: 86(19), pp: 2067-2079.

8. Mezarciöz, S., Mezarciöz, S. and Oğulata, R.T., 2014, "Prediction of air permeability of knitted fabrics by means of computational fluid dynamics". Journal of Textile \& Apparel/Tekstil ve Konfeksiyon, Vol: 24(2), pp: 202-211.

9. Dabiryan et al., 2018, "Simulating the structure and air permeability of needle-punched nonwoven layer". The Journal of The Textile Institute, Vol: 109(8), pp: 1016-1026.

10. Dehkordi et al., 2017, "Numerical Modelling of the Air Permeability of Knitted Fabric Using Computational Fluid Dynamics (CFD) Method". Fibers and Polymers, Vol: 18(9), pp: 1804-1809.

11. Siddiqui, M. and Sun, D., 2015, “Porosity Prediction of Plain Weft Knitted Fabrics”, Fibers, Vol: 3(1), pp: 1-11.

12. Siddiqui, M.O.R. and Sun, D., 2016, "Automated model generation of knitted fabric for thermal conductivity prediction using finite element analysis and its applications in composites", Journal of Industrial Textiles, Vol:45(5), pp:1038-1061.

13. Siddiqui, M.O.R. and Sun, D., 2017, “Conjugate heat transfer analysis of knitted fabric", Journal of Thermal Analysis and Calorimetry, Vol: 129(1), pp: 209-219.

14. Peirce, F.T., 1947, "Geometrical principles applicable to the design of functional fabrics", Textile Research Journal, Vol: 17(3), pp: $123-147$.

15. Hurd, J. and Doyle, P., 1953, “Fundamental aspects of the design of knitted fabrics”, Journal of the Textile Institute Proceedings, Vol: 44(8), pp:561-578.

16. Shinn, W., 1995, “An engineering approach to jersey fabric construction”, Textile Research Journal, Vol: 25(3), pp: $270-277$.

17. Leaf, G. and Glaskin, A., 1995, “The geometry of a plain knitted loop”, Journal of the Textile Institute Transactions, Vol: 46(9), pp: 587-605.

18. Leaf, G., 1960, "Models of the plain-knitted loop", Journal of the Textile Institute Transactions, Vol: 51(2), pp: 49-58.

19. Munden, D., 1959, "The geometry and dimensional properties of plain-knit fabrics", Journal of the Textile Institute Transactions, Vol: 50(7), pp: 448-471.

20. Postle, R., 1968, "Dimensional stability of plain-knitted fabrics", Journal of the Textile Institute, Vol: 59(2), pp: 65-77.

21. ASTM D737-96, 1996, "Standard Test Method for Air Permeability of Textile Fabrics", ASTM International, West Conshohocken, PA

22. Kurbak, A., 1998, "Plain knitted fabric dimensions (Part II)", Textile Asia, Vol: 78, pp: 36-44.

23. Demiroz, A. and Dias, T. , 2000, "A study of the graphical representation of plain-knitted structures part I: Stitch model for the graphical representation of plain-knitted structures", Journal of the Textile Institute, Vol: 91(4), pp: 463-480.

24. Gebart, B.R., 1992, "Permeability of unidirectional reinforcements for RTM”, Journal of Composite Materials, Vol: 26(8), pp: 1100-1133. 